Eduard I. Vatutin', Stepan E. Kochemazov², Oleq S. Zaikin ${ }^{3}$, DOI: 10.25045/jpit.v10.i2.01 Maxim O. Manzuk ${ }^{4}$, Natalia N. Nikitina ${ }^{5}$, Vitaly S. Titov ${ }^{6}$

${ }^{1,5}$ Southwest State University, Kursk, Russia

${ }^{2,3}$ Matrosov Institute for System Dynamics and Control Theory SB RAS, Irkutsk, Russia

${ }^{4}$ Internet-portal BOINC.ru, Moscow, Russia

${ }^{5}$ Institute of Applied Mathematical Research, Karelian Research Center of the RAS, Petrozavodsk, Russia

1evatutin@ rambler.ru, ${ }^{2}$ veinamond@gmail.com, ${ }^{3}$ zaikin.icc@ gmail.com, 4 hoarfrost@ rambler.ru, ${ }^{5}$ nikitina@krc.karelia.ru, ${ }^{6}$ titov-kstu@ rambler.ru

\title{
CENTRAL SYMMETRY PROPERTIES FOR DIAGONAL LATIN SQUARES
}

\author{
Received: 21.12.2018 Revised: 27.02.2019 Accepted: 10.03.2019
}

Latin squares and diagonal Latin squares are well known combinatorial objects connected with specific open mathematical problems. Most famous of them is the problem of existing triple of mutually orthogonal (diagonal) Latin squares of order 10 that are not proven or disproven at this moment. Best approximations of it is connected with symmetries (automorphisms) under Latin squares. Pseudo triple of diagonal Latin squares with world record 274 orthogonality characteristics is based on square with horizontal (plane) symmetry and it is shown that these characteristics can't be improved with this type of symmetry. In this work, we introduce a definition of different type of symmetry - the central symmetry for diagonal Latin squares and show the corresponding mathematical relations between the cells of the Latin square. Moreover, we describe the properties of the new symmetry and perform enumeration of corresponding squares of order 9 at most.

Keywords: diagonal Latin squares, symmetries, orthogonal mates, pseudo triples, orthogonality characteristics.

\section{Introduction}

One of the known types of combinatorial objects being applied in a variety of fundamental and applied fields of science are the Latin squares [1]. A Latin square (LS) of order $N$ is a square table $A=\left\|a_{i j}\right\|, i, j=\overline{1, N}$, filled with elements from some set $U$ with the cardinality property $N=|U|$ (for the sake of clearness, we will further assume that $U=\{0,1,2, \ldots, N-1\}$ ). By definition, each element from $U$ appears exactly once in each row and each column of a Latin square. For diagonal Latin squares (DLS) which are a special case of LS, by definition, there are additionally introduced requirements of no coinciding elements on their main diagonal and main antidiagonal (main diagonal and main antidiagonal are transversals).

A DLS is called normalized if the elements of its first row are sorted in ascending order. It is easy to show that one can normalize any correct DLS by means of a bijective mapping (transposition) of elements from $U$, and the indicated set of diagonal Latin squares forms an equivalence class of $N$ ! DLSs. For a number of problems, the squares within the equivalence class do not differ since they all possess same properties (existence/absence of an orthogonal mate, the number of transversals etc.), which allows to reduce the runtime in any corresponding computational experiment significantly. A canonical form of DLS is the lexicographically minimal DLS within the corresponding isomorphism class (isotopy class in this case) obtained using $M$-transformations by Yu. Chebrakov (for $N=10$, the indicated class contains at most 15360 DLSs).

A pair of orthogonal diagonal Latin squares (ODLSs) is a pair of DLSs $A$ and $B$ where all ordered pairs $\left(a_{i j}, b_{i j}\right), i, j=\overline{1, N}$ are unique (such pairs of squares are also called Graeco-Latin squares). The construction of ODLSs is a computationally complex combinatorial problem which is being solved, mostly efficiently, using transversals within Euler-Parker approach [2]. Another computationally complex problem is that of constructing systems of mutually orthogonal LSs and DLSs (MOLSs and 
MODLSs, correspondingly). For the DLSs of order 10, it is an open mathematical problem either to prove or disprove the existence of a triple of mutually orthogonal Latin squares.

Additional direction of the combinatorial problems is related to the enumeration of some objects (Latin squares of different types, pairs of MOLS/MODLS, transversals, etc.) depending on the size of a problem $N$. The team of authors has identified a series of combinatorial characteristics of DLSs (values for some of them had been known before for LSs, but not for DLSs):

- the number of DLSs of order $N$, sequences A274171 and A274806 in OEIS [3-7];

- minimum and maximum number of transversals and diagonal transversals for DLSs of order $N$, sequences A287645, A287644, A287647 and A287648 in OEIS [8, 9];

- the number of one-plane and two-plane symmetric DLS of order $N$, sequences A287649, A287650, A292516, A292517, A296060 and A296061 in OEIS [10];

- the number of reduced (first row of DLSs has an ascending order) pairs of ODLS of order $N$, sequence A287651 in OEIS [11, 12];

- the maximum number of ODLS for one DLS of order N, sequence A287695 in OEIS [12].

\section{Definition of symmetries and computing experiments}

At present, such triple has neither been found nor proven to be non-existent. The best approximation of the solution of this problem, for the moment, has been found by authors of [13]: it is a pseudotriple of squares $A, B$ and $C$ (figure 1), where the pairs $A B$ and $A C$ are orthogonal, while the pair $A C$ is orthogonal in 74 cells (the total orthogonality characteristic of this triple equals 274 ).

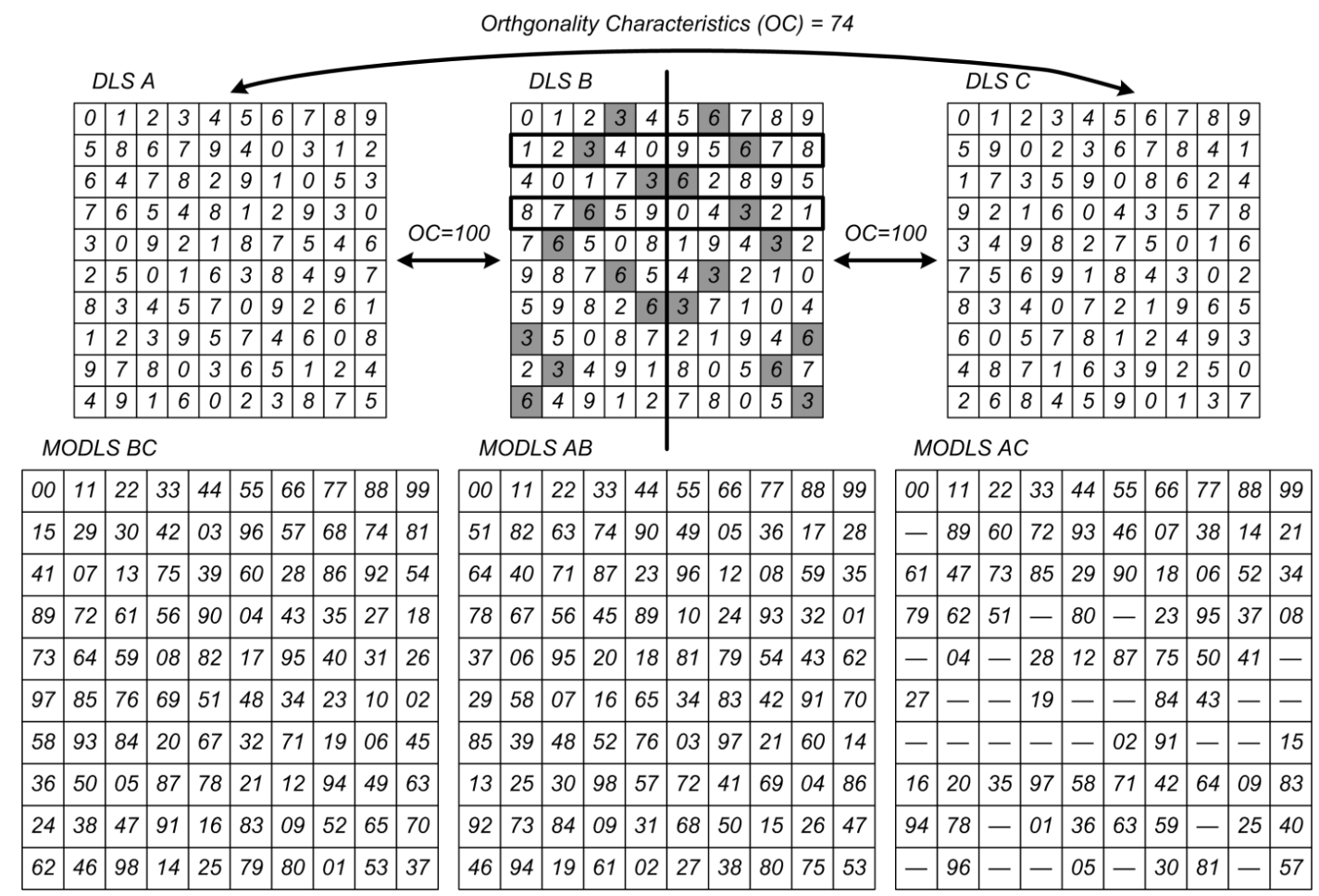

Figure 1. Pseudotriple of DLS of order 10 with record orthogonality characteristics equal to $100+100+74=274$. The vertical bold line is the axis of symmetry of square $B$. Symmetrically placed pairs of values 3 and 6 are highlighted in gray for illustrating the symmetry Bold rectangles are shows as an example of inversion of the rows for square $B$. The arrows indicate the corresponding orthogonality characteristics for pairs of squares $A B, A C$ and $B C$ within pseudotriple. The bottom part of the figure shows the pairs of values with corresponding pairs of squares; violations are marked with dashes.

The square $B$ forming this pseudotriple is symmetric in one plane (for definiteness, horizontal one) [14] and is row-inverse (5 of its rows are generated by writing down the elements of other 5 rows in reverse order). At first, squares of this type were shown in [15]. 
The authors have conducted a series of computational experiments within the volunteer computing project Gerasim@ $@$ Home $^{1}$ based on BOINC platform [16]. During the experiments, all possible canonical forms of the DLSs were constructed that are symmetric in one plane and, at the same time, include row-inverse DLSs. This has not allowed to increase the previously found orthogonality characteristic. For DLSs of lower orders, some interesting combinatorial structures (graphs from DLSs in which arcs present if corresponding pair of DLSs are orthogonal mates) do exist for twice symmetric DLSs as well (having symmetry both in horizontal and in vertical planes); however, such DLSs do not exist for order $N=10$. For combinatorial structures basing on non-symmetric DLSs, orthogonality characteristics are significantly lower (for instance, this characteristic equals 12 for most of the found structures of type Line-3 («twice») [17]) which makes it advantageous to search for new symmetries in DLSs while attempting to improve the given orthogonality characteristic.

The plane symmetries are considered above set bijection between the values of the elements situated symmetrically in relation to vertical and/or horizontal straight lines passing through the square's center (relations $[i, j] \Leftrightarrow[i, N-j-1]$ and $[i, j] \Leftrightarrow[N-i-1, j]$ ). From the school course of geometry, one knows another type of symmetry: the symmetry with respect to a point. The simplest attempt of finding such a symmetry in DLS is to locate the given center of symmetry in square's center, the mathematical relation being $[i, j] \Leftrightarrow[N-i-1, N-j-1]$. An example of such DLS of order 9 is provided in figure 2.

\begin{tabular}{|l|l|l|l|l|l|l|l|l|}
\hline 0 & 1 & 2 & 3 & 4 & 5 & 6 & 7 & 8 \\
\hline 6 & 3 & 0 & 2 & 7 & 8 & 1 & 4 & 5 \\
\hline 3 & 2 & 1 & 8 & 6 & 7 & 0 & 5 & 4 \\
\hline 7 & 8 & 6 & 5 & 1 & 3 & 4 & 0 & 2 \\
\hline 8 & 6 & 4 & 7 & 2 & 0 & 5 & 3 & 1 \\
\hline 2 & 7 & 5 & 6 & 8 & 4 & 3 & 1 & 0 \\
\hline 5 & 4 & 7 & 0 & 3 & 1 & 8 & 2 & 6 \\
\hline 4 & 5 & 8 & 1 & 0 & 2 & 7 & 6 & 3 \\
\hline 1 & 0 & 3 & 4 & 5 & 6 & 2 & 8 & 7 \\
\hline
\end{tabular}

Figure 2. Example of a centrally-symmetric DLS of order 9 (the matches between the elements of values 0 and 7 are in gray; part of them are marked by arrows)

For the purpose of finding DLS with such symmetry, we used the previously developed exhaustive-enumeration DLSs generator $[18,19]$ with a following check of the generated DLSs for having the desired central symmetry. With its help, the corresponding computational experiment was conducted and allowed to define the number of normalized centrally-symmetric DLSs of order $1 \leq N \leq 8: 1,0,0,2,8,0,2816,135168$ (magic squares having a similar type of central symmetry are called associative in the literature).

For the order of $N=9$, calculation of the number of centrally-symmetric DLSs using the proposed approach will require several months of grid computations [7]. For this reason, we have implemented a specialized generator of DLSs having the property of central symmetry. Its correctness was tested on the numbers of DLSs of small orders given above; then, in 19 minutes on a Core i7 4770 processor in one thread, the generator defined the number of normalized centrally-symmetric DLSs of order 9, amounting to 327254016 . The number of centrallysymmetric DLSs of general kind (not necessarily normalized) can be obtained from the values provided above with their multiplication by $N$ ! constituting the following sequence: $1,0,0,48$, 960, 0, 14192 640, 5449973 760, 118753937326 080. These sequences are new, they have been added to the Online Encyclopedia of Integer Sequences [20] under A293777 and A293778

${ }^{1}$ http://gerasim.boinc.ru 
identifiers. Their extension onto larger orders of DLSs does not seem possible without the employment of computational facilities with parallel architecture.

Using the developed generator at this time, the following empirical feature has been detected and partially checked for orders $N \leq 25$ : it appears that centrally-symmetric DLSs exist only for orders $N \neq 4 n+2, n \in \square, n \geq 0$ (of course, excluding the case $N=3$ for which DLS do not exist at all). Unfortunately, this does not allow for constructing combinatorial structures with high orthogonality characteristics for our target case $N=10$ basing on the central symmetry.

In common with the previously found types of symmetry, the presented centrally-symmetric DLSs, as a rule, have a large number of ODLSs. For instance, there exist 47 ODLSs for the DLS of order 9 provided in figure 2 . At the same time, the majority of DLSs without symmetries have at most 1 ODLS. For the case of $N=9$, we organized a computational experiment allowing to construct ODLSs for all DLSs having the property of central symmetry. As a result, the following DLS has been found:

$$
\left(\begin{array}{lllllllll}
0 & 1 & 2 & 3 & 4 & 5 & 6 & 7 & 8 \\
6 & 7 & 8 & 0 & 1 & 2 & 3 & 4 & 5 \\
3 & 4 & 5 & 6 & 7 & 8 & 0 & 1 & 2 \\
5 & 3 & 4 & 8 & 6 & 7 & 2 & 0 & 1 \\
2 & 0 & 1 & 5 & 3 & 4 & 8 & 6 & 7 \\
8 & 6 & 7 & 2 & 0 & 1 & 5 & 3 & 4 \\
7 & 8 & 6 & 1 & 2 & 0 & 4 & 5 & 3 \\
4 & 5 & 3 & 7 & 8 & 6 & 1 & 2 & 0 \\
1 & 2 & 0 & 4 & 5 & 3 & 7 & 8 & 6
\end{array}\right) .
$$

It has 516 orthogonal DLSs (a record high for the order of $N=9$, see the sequence A287695 in OEIS [12]. On top of that, the DLS found has a number of interesting properties:

- The first 3 rows completely coincide with pandiagonal rows (obtained by cyclic rotation of the row «0 12345678 » by 3 and 6 .

- The remaining rows (groups of rows 2-5, 6-8) are also similar to pandiagonal rows: they are obtained with the cyclic rotation by 3 and by 6 , but have a different order of elements.

- The square is self-orthogonal (SODLS) for transformations of reflection from both diagonals, rotations and reflections vertically and horizontally.

- The highest orthogonality characteristic of a pseudo triple on its basis equals 81 .

\section{Conclusion}

This paper has described a new type of symmetries for DLS. Corresponding DLSs are enumerated for $N \leq 9$ and it is shown that DLSs with this type of symmetry produce interesting combinatorial structures; however, those probably do not exist for $N=10$ which does not allow to use it for increasing the well known orthogonality characteristics for pseudo triples of DLSs.

Currently, the team of authors is looking for additional symmetries in DLSs which can potentially improve the record of orthogonality characteristics stated above. The corresponding experiments are being performed within the framework of the volunteer computing project Gerasim@Home. In the volunteer computing project RakeSearch ${ }^{2}$, the search for ODLSs is currently being carried out for order of 9. Basing on a feature of this particular order allows to obtain ODLSs by permutations of rows of the original DLS much faster than using the universal Euler-Parker method.

\section{Acknowledgements}

The authors of the paper express gratitude to citerra [Russia Team] from the Internet-portal BOINC.ru for his help in implementing some of the algorithms and finding a number of combinatorial

\footnotetext{
${ }^{2} \mathrm{http} / / /$ rake.boincfast.ru/rakesearch/
} 
structures with unique characteristics. The work was partially supported by the Russian Foundation for Basic Research (projects 16-07-00155-a, 17-07-00317-a, 18-07-00628-a, 18-37-00094-mol-a) and the Russian Federation President Council on Grants (scholarship SP-1829.2016.5).

\section{References}

1. Colbourn C.J., Dinitz J.H. Handbook of Combinatorial Designs, Second Edition. Chapman I\& Hall/CRC, 2006, 1016 p.

2. Wanless I.M. Transversals in Latin Squares: A Survey // arXiv:0903.5142 [math.CO], 2009. 35 p.

3. Bammel S.E., Rothstein J. The number of 9x9 Latin squares // Discrete Math., 1975, vol.11, pp.93-95.

4. Brown J.W. Enumeration of Latin squares with application to order 8 // Journal of Combinational Theory, 1968, vol.5, issue 2, pp.177-184.

5. Kochemazov S.E., Vatutin E.I., Zaikin O.S. Fast Algorithm for Enumerating Diagonal Latin Squares of Small Order // arXiv:1709.02599 [math.CO], 2017.

6. Vatutin E.I., Kochemazov S.E., Zaikin O.S. Applying Volunteer and Parallel Computing for Enumerating Diagonal Latin Squares of Order 9 / International conference Parallel Computational Technologies (PCT 2017). Communications in Computer and Information Science, vol.753, pp.114-129. DOI: 10.1007/978-3-319-67035-5\_9.

7. Vatutin E.I., Zaikin O.S., Zhuravlev A.D., Manzyuk M.O., Kochemazov S.E., Titov V.S. Using grid systems for enumerating combinatorial objects on example of diagonal Latin squares / CEUR Workshop proceedings. Selected Papers of the 7th International Conference Distributed Computing and Grid-technologies in Science and Education, 2017, vol.1787, pp. 486-490.

8. Vatutin E.I., Kochemazov S.E., Zaikin O.S., Valyaev S.Yu. Enumerating the Transversals for Diagonal Latin Squares of Small Order // CEUR Workshop Proceedings. Proceedings of the Third International Conference BOINC-based High Performance Computing: Fundamental Research and Development (BOINC:FAST 2017). Vol. 1973. Technical University of Aachen, Germany, 2017, pp. 6-14. urn:nbn:de:0074-1973-0.

9. Vatutin E.I., Kochemazov S.E., Zaikin O.S., Valyaev S.Yu. Using Volunteer Computing to Study Some Features of Diagonal Latin Squares // Open Engineering, vol.7, no.1. 2017, pp. 453-460. DOI: 10.1515/eng-2017-0052.

10. Vatutin E.I., Kochemazov S.E., Zaikin O.S. On Some Features of Symmetric Diagonal Latin Squares / CEUR WS, 2017,vol.1940, pp.74-79.

11. Egan J., Wanless I.M. Enumeration of MOLS of small order // Mathematics of Computation, vol.85, 2016, pp.799-824.

12. Vatutin E.I., Kochemazov S.E., Zaikin O.S., Manzyuk M.O., Titov V.S. Combinatorial characteristics estimating for pairs of orthogonal diagonal Latin squares (in Russian) // Multicore processors, parallel programming, FPGA, signal processing systems. Barnaul: Altay State University, 2017, pp.104-111.

13. Zaikin O., Zhuravlev A., Kochemazov S., Vatutin E. On the Construction of Triples of Diagonal Latin Squares of Order 10 // Electronic Notes in Discrete Mathematics, vol. 54C. 2016, pp.307-312. DOI: 10.1016/j.endm.2016.09.053.

14. Vatutin E.I., Kochemazov S.E., Zaikin O.S., Titov V.S. Investigation of symmetric diagonal Latin squares properties. Correction work (in Russian) // Intellectual and information systems (Intellect - 2017). Tula, 2017, pp.30-36.

15. Brown J.W., Cherry F., Most L., Most M., Parker E.T., Wallis W.D. Completion of the spectrum of orthogonal diagonal Latin squares // Lecture notes in pure and applied mathematics, 1992, vol.139, pp.43-49.

16. Anderson D.P., Fedak G. The Computational and Storage Potential of Volunteer Computing / Sixth IEEE International Symposium on Cluster Computing and the Grid (CCGrid 2006), 
16-19 May 2006, Singapore. pp.73-80.

17. Vatutin E.I., Titov V.S., Zaikin O.S., Kochemazov S.E., Manzyuk M.O. Analysis of combinatorial structures on the orthogonality relation set of diagonal Latin squares of order 10 (in Russian) // Information technologies and mathematical modeling of systems. Moscow, Design Informational Technology Center of the RAS, 2017, pp.167-170.

18. Vatutin E.I., Titov V.S., Zaikin O.S., Zhuravlev A.D., Manzyuk M.O., Kochemazov S.E., Fedorov S.S. Program for recurrent enumerating of diagonal Latin squares of selected order using brute force approach and its modifications (in Russian). Certificate of official registration of the computer software No. 2016662287 from 07.11.16.

19. Vatutin E.I., Zaikin O.S., Zhuravlev A.D., Manzyuk M.O., Kochemazov S.E., Titov V.S. The effect of filling cells order to the rate of generation of diagonal Latin squares (in Russian) // Information-measuring and diagnosing control systems (Diagnostics - 2016). Kursk: SWSU, 2016, pp.33-39.

20. Sloanne N.J.A. Online Encyclopedia of Integer Sequences. URL: http://oeis.org

\section{UOT 004.75}

Vatutin Eduard I.. ${ }^{1}$, Koçemazov Stepan E. ${ }^{2}$, Zaikin Oleq S. ${ }^{3}$, Manzyuk Maksim O. ${ }^{4}$, Nikitina Natalya N. ${ }^{5}$, Titov Vitaliy $S^{6}{ }^{6}$

${ }^{1}$ Cənub-Qərb Dövlət Universiteti, Kursk, Rusiya

${ }^{2,3}$ Sistemlərin Dinamikası və İdarəetmə Nəzəriyyəsi İnstitutu, İrkutsk, Rusiya

${ }^{4}$ BOINC.ru İnternet-portal1, Moskva, Rusiya

${ }^{5}$ Rusiya Elmlər Akademiyasının Karel Elmi Mərkəzinin Tətbiqi Riyaziyyat Tədqiqatları

İnstitutu, Petrozavodsk, Rusiya

${ }^{6}$ Cənub-Qərb Dövlət Universiteti, Kursk, Rusiya

${ }^{1}$ evatutin@ rambler.ru, ${ }^{2}$ veinamond@gmail.com, ${ }^{3}$ zaikin.icc@gmail.com, ${ }^{4}$ hoarfrost@ rambler.ru, 5 nikitina@krc.karelia.ru, ${ }^{6}$ titov-kstu@ rambler.ru

Diaqonal latın kvadratlarında mərkəzi simmetriya xüsusiyyətlərinin tədqiqi

Məqalədə diaqonal latın kvadratlarında (DLK) mərkəzi simmetriyanın müəyyən olunması məsələləri araşdırılmış, kvadrat sətirləri arasında onu müəyyən edən riyazi əlaqələr təsvir edilmiş, onun xüsusiyyətləri, həmçinin $\mathrm{N}<10$ ölçüləri üçün göstərilən simmetriyaya malik olan DLK-ların sayı müəyyən edilmişdir.

Açar sözlor: diaqonal latın kvadratlarl, simmetriyalar, ortoqonal diaqonal latın kvadratları, psevdo üçlü, ortoqonallığın xüsusiyyatlari.

\section{УДК 004.75}

Ватутин Эдуард И. ${ }^{1}$, Кочемазов Степан Е. ${ }^{2}$, Заикин Олег С. ${ }^{3}$, Манзюк Максим О. 4 , Никитина Наталья Н. ${ }^{5}$, Титов Виталий С. ${ }^{6}$

${ }^{1}$ Юго-Западный государственный университет, Курск, Россия

2,3 Институт динамики систем и теории управления СО РАН, Иркутск, Россия

${ }^{4}$ Интернет-портал BOINC.ru, Москва, Россия

${ }^{5}$ Институт прикладных математических исследований Карельского научного центра РАН, Петрозаводск, Россия

${ }^{6}$ Юго-Западный государственный университет, Курск, Россия

1evatutin@ rambler.ru, ${ }^{2}$ veinamond@gmail.com, ${ }^{3}$ zaikin.icc@gmail.com, ${ }^{4}$ hoarfrost@ rambler.ru, 5 nikitina@krc.karelia.ru, ${ }^{6}$ titov-kstu@ rambler.ru

Исследование свойств центральной симметрии в диагональных латинских квадратах В работе приведено определение центральной симметрии в диагональных латинских квадратах (ДЛК), описаны определяющие ее математические соотношения между ячейками квадрата, ее свойства, а также определено число ДЛК, обладающих указанной симметрией, для размерностей $\mathrm{N}<10$.

Ключевые слова: диагональные латинские квадраты, симметрии, ортогональные диагональные латинские квадраты, псевдотройки, характеристики ортогональности. 